ФИЛОСОФИЯ

3. Ицков Д. И. Общественное движение «Россия 2045» и глобальное будущее // Глобальное будущее 2045: Антропологический кризис. Конвергентные технологии. Трансгуманистические проекты : материалы Первой Всерос. конфф., Белгород, 11-12 апреля 2013 г. / под ред. Д. И. Дубровского, С. М. Климовой. М. : Канон+, 2014. С. 8-14.

4. Дёмин И. В. Бессмертие как проект: смерть и бессмертие человека в контексте гуманистического и трансгуманистического типов мировоззрения // Онтология проектирования. 2013. № 4 (10). С. 7-17.

5. Курцвейл Р., Гроссман T. Transcend: девять шагов на пути к вечной жизни. М. : Манн, Иванов и Фербер, 2015. 384 c.

6. Дубровский Д. И. Природа человека, массовое сознание и глобальное будущее // Глобальное будущее 2045: Антропологический кризис. Конвергентные технологии. Трансгуманистические проекты : материалы Первой Всерос. конф., Белгород, 11-12 апреля 2013 г. / под ред. Д. И. Дубровского, С. М. Климовой. М. : Канон+, 2014. C. 188-199.

7. Харари Ю. H. Homo Deus. Краткая история будущего. М. : Синдбад, 2018. 496 с.

8. Тегмарк М. Жизнь 3.0. Быть человеком в эпоху искусственного интеллекта. М. : АCT : CORPUS, 2019. 560 с.

9. Фукуяма Ф. Наше постчеловеческое будущее: Последствия биотехнологической революции. М. : АСТ : ЛЮКС, 2004. 349 с.

УДК 7.01

Науч. спец. 09.00 .01

DOI: 10.36809/2309-9380-2020-29-20-22

\section{ПРОСТРАНСТВО МУЗЕЯ В КИТАЕ: КЛОНИРОВАНИЕ ИЛИ ПРОРЫВ В НОВОЕ ЭСТЕТИЧЕСКОЕ ПРОСТРАНСТВО?}

В статье рассматривается феномен китайского тиражирования. Предпринята попытка выявить причины и следствия такого масштабного тиражирования как одного из ведущих направлений развития современных культурных индустрий при поддержке государственной политики Китайской Народной Республики (КНР). Репродуцирование рассмотрено как начальная ступень созидательности нового пространства, где оригинальность и новизна противопоставляются полноте.

Ключевые слова: оригинальность, тиражирование, уникальное, копия, реплика, искусство Китая, музей подделок.
10. Хабермас Ю. Будущее человеческой природы / пер. с нем. М. : Весь Мир, 2002. 144 с.

11. Курцвейл Р. Эволюция разума. М. : Э, 2015. 352 с.

12. Старцева В. С. Исторические модификации трансгуманизма // Сетевой научный журнал ОрелГАУ. 2017. № 1 (8). C. $152-157$.

13. Кувакин В. А. Твой рай и ад: Человечность и бесчеловечность человека (Философия, психология и стиль мышления гуманизма). СПб. : Алетейя ; М. : Логос, 1998. 360 с.

14. Черкозьянова Т. В. Смыслообразующие функции смерти в культурогенезе : дис. ... канд. филос. наук. М., 2003. $142 \mathrm{C}$.

15. Изотов М. О. О возможности свободы в любви // Свобода совести и диктатура миросозерцания: История взаимоотношений и современные реалии : коллективная монография. Орел : Издательство Картуш, 2016. С. 111-115.

16. Флоренский П. А. Столп и утверждение истины: Опыт православной теодицеи. М. : АСТ, 2003. 640 с.

17. Бухаров Д. Н. Тело как приоритетная ценность и ее влияние на идентичность человека // Вестн. Нижегор. ун-та им. Н. И. Лобачевского. Серия: Социальные науки. 2012. № 3 (27). С. 109-115.

18. Хольм С. Философркие проблемы в оценке постчеловеческого будущего // Человек. 2016. № 4. С. 5-15.

(C) Изотов М. О., 2020

\title{
MUSEUM SPACE IN CHINA: CLONING OR BREAKTHROUGH INTO A NEW AESTHETIC SPACE?
}

The article examines the phenomenon of Chinese replication. An attempt is made to identify the causes and consequences of such a large-scale replication as one of the leading areas of development of modern cultural industries with the support of the state policy of the PRC. Reproduction is considered as the initial stage of creativity in a new space, where originality and novelty are opposed to completeness.

Keywords: originality, replication, unique, copy, replica, Chinese art, Museum of forgeries.

Тема подделки и репродукции произведений искусства всегда была актуальной для сферы искусства. Сейчас эта тема, ввиду всё большего распространения производства реплик, привлекает внимание специалистов разных областей: подделку можно обнаружить как в контексте эстетики, семантики, юриспруденции, так и в технологиях. Соответ-

ственно, цель данной работы - прояснение статуса репродукции и ее функций в современном социокультурном пространстве.

Если в технической сфере китайское всеобъемлющее копирование, очевидно, становится угрозой интеллектуальной собственности, приводит к миллиардным ущербам и ак- 
тивно оспаривается в европейских судах, то в сфрере искусства китайские эстетисты, однако не без участия западных, заявляют копирование не как свой недостаток, а подают его как достоинство, создавая музей, состоящий исключительно из подделок мировых шедевров живописи, которые представляют китайскому зрителю, существующему вне этого эстетического контекста, и пытаются тем самым породить новые смыслы. Тираж выступает как помощник оригинала. «Можно констатировать возврат человека... к уникальному творению, новое осознание фонда уникального (в самом широком смысле этого понятия) в значении непреходящих ценностей человеческой культуры» [1, с. 158].

«Воцарение культуры апроприации и переработки всех форм установило новую мораль: произведения принадлежат всем. Современное искусство стремится к отмене собственности на формы, во всяком случае - к коренному пересмотру связанных с нею традиционных юридических конвенций» [2, с. 144]. Тенденция, зародившаяся еще в конце прошлого столетия, достигла своего апогея в «Музее подделок», расположенном в мировой столице подделок - г. Гуанчжоу, на юге КНР, распространяя идеи коммунизма не только на государственное устройство, но и на ссреру искусства: «Современное искусство стремится к отмене собственности на формы, во всяком случае к коренному пересмотру связанных с нею традиционных юридических конвенций. Не ждет ли нас впереди культура, в которой копирайт уступит место гибкому регулированию права доступа к произведениям - в принципе всеобщего? Не намечается ли в будущем коммунизм фрорм?» [2, с. 144]

«Произведение искусства всё реже и реже представляет собой уникальный объект, оригинал, созданный индивидуальным художником. Сегодня в живописи наблюдается тенденция к созданию репродуцируемых объектов» [3, с. 195]. Этим и решили воспользоваться современные китайские деятели искусства. Музей копий отражает государственную политику формирования китайца на мировом рынке: с помощью брендинга идет выращивание культурного человека, отчасти включенного в мировой опыт и культуру глобального. «В Китае вследствие необъективируемости исходных посылок традиции переход к современной национальной идеологии оказался крайне затруднительным и по сию пору незавершенным» [4, с. 554], и в создании культурных брендов китайцы пытаются совместить ценности традиционной и социалистических культур. Исследованием культурных брендов занимается Центр исследования брендов китайских культурных индустрий при Центрально-Южном университете в КНР. Научный коллектив Центра составляют ведущие ученые в области философии и теории культуры, маркетологии и маркетинга, межкультурной коммуникации, рассматривающие культурный бренд как искусственно конструируемое явление современной культуры и инструмент коммуникации в условиях межкультурного взаимодействия. «Культурный бренд в этой стратегии становится одним из инструментов конструирования модели развития китайской цивилизации» [5, с. 7].

Сама идея экспозиции произведений искусства чужда традиции Китая: «картина, вопреки нашему обычаю, не предназначена для постоянной экспозиции. Ее выбирают и разворачивают по случаю, согласно моменту» [6, с. 256].
«Музей подделок» можно воспринять как насмешку, ведь пространство музея всегда обозначалось как хранилище уникальных произведений искусства. Его практическое назначение в наши дни - концентрация и сохранение подлинников для удобства их копирования и тиражирования. При этом чем больше копий данного подлинника расходится среди публики, тем выше его ценность. «Приблизить вещи и очеловечить их есть столь же страстное желание современных масс, как и тенденция преодолевать уникальность явления через его репродуцирование» [7, с. 42]. В западной культуре проблема оригинала и копии всё сильнее обостряется в связи с появлением новых средств репродукции. В Китае апроприацию возводят в ранг главенствующего принципа, позволяющего создавать новые музеи и писать новую историю, где копия обладает собственным нарративом, независимым от нарратива оригинала и даже, возможно, более значимым в рамках современного искусства или истории в целом.

Однако в Китае пошли по иному пути, не создавая новых техник, художественных средств и видов искусства. Создание музея копий как метанарратива истории искусства не для того, чтобы его уничтожить, а для того, чтобы задать новые векторы развития в будущем, так как форма существования данных артефактов как произведений искусства в рамках эстетического пространства исчерпана. Они должны стать внеположны искусству и обрести новые смыслы. «Это не музей современного искусства. Это музей о музее современного искусства, место, где хранится в памяти и остается актуальным современное искусство и где эта память скорее будет памятью о настоящем и будущем, чем о прошлом» [8, с. 174].

Импортная продукция ценится выше, чем подобная, но китайского производства. Однако оригинальных продуктов зачастую не существует, и ввиду ограниченности выбора или наличия исключительно реплик это позволяет продавать копии еще дороже оригинала, так как, во-первых, он зачастую недосягаем, во-вторых, воспринимается китайцами как оригинал. Итак, потребление копий, независимо от того, является ли копия отсылкой к оригиналу или же выдается за него, так или иначе, ввиду ее причастности к оригиналу, считается престижным и наделяет своего обладателя определенной статусностью, возвышая его над теми, кто потребляет оригинальную продукцию китайского производства. Между традицией и современным тиражированием простирается пропасть, которую, возможно, китаец и старается заполнить как можно большим количеством артесактов, предметов, историй, пусть и искусственно созданных или воссозданных, что уже зависит от определенного контекста.

На дальнейшее развитие музейного пространства в Китае есть два взгляда: с одной стороны, это отказ китайцев от собственной культуры, с другой - это аналогия с техническим развитием и чудом китайской индустриализации, которое, несмотря на доминирование мнения о воровстве технологий, перерастает в собственное создание китайцами новых технологий. Из этого следует, что китайское руководство, допускающее развитие западных музеев копий, планирует такой же переход от копирования к творчеству в эстетическом пространстве.

Отметим, что развитие пространства искусства в Китае отталкивается от пространства и образцов Запада и Аме- 
рики, а также предполагает лояльность к распространению подделок среди потребителей. «Постмодернизм ценил репродукцию выше продукции, вторичность выше подлинности, анонимность выше индивидуальности» [9, с. 218]. Воспользовавшись принципами европейского постмодернизма, технологией массового производства копий и созданием рынка копий, китайцы представляют некую начальную стадию прорыва к новому эстетическому пространству. Это и есть китайский метод внедрения новых пространств, технологий через клонирование его в самом Китае. Обратимся к концепту лабиринта Ж.-Ф. Лиотара как экзистенциальной реальности субъекта и пространству ужаса серии [10, с. 61-75]. Если дорогу запоминаешь и видишь повторения, то нет лабиринта, можно найти обратный путь. Ужас порождает лабиринт. Лабиринт - пространство ужаса. Лабиринт - стремление к полному повторению: с одной стороны, к предельной интенсивности старого переживания; с другой — к его возобновлению или исчезновению; внешнее - полная пошлость; внутреннее - одержимость и безумие. Еще одна странность лабиринта заключается в том, что субъект стремится к повторению чувства и реальности, но получает серию. Таким образом, серия - внешнее проявление лабиринта и присутствия реальности в субъекте. Присутствие дано вовне как повторяемость. Мы не можем прочувствовать реальность субъекта, его ужас, но мы видим повтор. Он же повтора не видит, потому и попадает в ужас лабиринта. Извне серия нелепа, кажется, субъект наивно застрял в своей пустоте. Пространственно лабиринт делит мир на место встречи и остальное. Парадокс лабиринта в том, что чувство дает себя в полноте повторения, а жажда нового - глупость чувства. Это напоминает известный феномен: человека утомляет новое, а то, что ему нравится, он стремится повторить. Но западный человек бежит от повторения и стремится к новизне. Можно ли сказать, что повторение - структура бытия, а новизна - основание существования?

Парадокс китайцев в том, что они не стесняются копировать, они стремятся не к новизне и оригинальности, а к удобству и полноте. В их культуре совершенно иная структура эмоциональности, что отражается на отношении к повторению и структуре чувственности в европейском понимании. Нет той экзальтации новизны и поиска нового, как у европейца. Такой подход дает возможность тиражирования без возмущения плагиатом и наивностью копирования. Китаец, не стремясь к новизне, к обладанию шедевром, просто ищет полноты, а не оригинальности. Он не понимает погони за единственным, а европеец - примитивизма музея подделок. Ж.-Ф. Лиотар приходит к выводу об эфемерности повторения, но мы видим тут иную топику чувственности, восточный человек живет в ином пространстве, которое более адекватно в отношении к внутреннему протеканию чувства и страсти. Человек в сериации зацикливается на важном для его реальности переживании.

Для европейца важно неповторимое присутствие вещи, китайцу - напоминание о собственном знакомстве с предметом. Таким образом, уникальный предмет вызывает у европейца страсть, стыд, жадность, а китаец исходно равнодушен, ему годится и копия, память, так ему легче сохранить объективность. Парадокс в том, что китаец в от- ношении произведения искусства в большей степени остается субъектом, не утрачивая себя в страсти, а европеец, подчеркивающий свою самость, утрачивает субъективность в страсти, подчиняется логике предмета, как бы овеществляет свою самость и уникальность в уникальности предмета. Китаец же не будет овеществлять себя в предмете. Он хочет иметь метку на память, а не то, в чем он утонет и исчезнет как субъект.

Это дает методологическое основание для понимания разности европейской и китайской субъективности. Европеец ищет предмет, обладающий уникальной субъективностью и овеществляет себя в обладании таким предметом, а китаец ищет предмет, напоминающий о присутствии оригинала, что поддерживает в человеке его субъективность.

Предмет коллекции европейца уникален и вокруг него возникает аура самоутраты, отключающая ресрлексию и память, воспоминание и размышление, она действует наркотически; предмет коллекции китайца вызывает рефлексию и воспоминание. В итоге предмет коллекции европейца - это демон в его доме, отбирающий его самость, а предмет коллекции китайца притягивает в его дом его память, его приключение, т. е. сосредотачивает его Я. В такой ситуации европеец ревнует к предмету другого, охраняет и защищает свое и боится утраты, а китаец - не может утратить. Это и есть иное отношение к другому и своему, к своей собственности и к коллективности, т. е. субъективность китайца обнаруживает его иную социальность и отношение к собственности. Таким образом, мы видим, что характер повторения, играющий ключевую роль в европейской культуре и искусстве и особенную в европейском постмодернизме, в китайской культуре обладает иным содержанием и субъективностью.

1. Зоркая Н. М. Уникальное и тиражированное: средства массовой информации и репродуцированное искусство. М. : Искусство, 1981. 167 с.

2. Буррио Н. Реляционная эстетика. Постпродукция. М. : Ад Маргинем Пресс, 2016. 240 с.

3. Сонтаг С. О фотографии. М. : Ад Маргинем Пресс : Музей современного искусства «Гараж», 2020. 272 с.

4. Малявин В. Сумерки Дао: культура Китая на пороге Нового времени. М. : АСТ, 2019. 560 с.

5. Ни Цзяоцзяо. Феномен культурного бренда в современной китайской культуре : автореф. дис. ... канд. филос. наук. Чита, 2019. 25 с.

6. Жюльен Ф. Великий образ не имеет формы, или Через живопись - к не-объекту. М. : Ад Маргинем Пресс, 2014. 368 c.

7. Беньямин В. Произведение искусства в эпоху его технической воспроизводимости. М. : Медиум, 1996. 121 с.

8. Вальтер Беньямин: новые сочинения. М. : ЦЭМ : V-A-C press, 2017. $232 \mathrm{C}$.

9. Гройс Б. Частные случаи. М. : Ад Маргинем Пресс : Музей современного искусства «Гараж», 2020. 220 с.

10. Лиотар Ж.-Ф. Либидинальная экономика. М. : Изд-во ин-та Гайдара, 2018. 472 с.

(C) Кириченко Е. В., 2020 